\title{
Old and New Air Pollutants: An Evaluation on Thirty Years Experiences
}

\author{
Margherita Ferrante, Maria Fiore, Gea Oliveri Conti, Caterina Ledda, \\ Roberto Fallico and Salvatore Sciacca
}

Additional information is available at the end of the chapter

http://dx.doi.org/10.5772/47820

\section{Introduction}

Air pollutants are generally defined as those substances which alter the composition of the natural atmosphere.

Emissions of air pollutants derive from almost all economic and societal activities but also by natural disaster (eg.: particulate matter or gaseus emitted by volcanic activities or forest fires, dust by desert winds, pollen scattering, sea aereosol, etc..). The energy production and the general industry activity, all types of transport and agriculture are key emission sources of air pollutants. They result in clear risks to human health and the ecosystems integrity. Air pollution is not only a local phenomenon but also a transboundary issue, in fact, the air pollutants emitted in one Country may be transported in the atmosphere and they harming human health and the environment elsewhere .

In Europe, policies and actions at all levels have greatly reduced the anthropogenic emissions and exposure but some air pollutants still harm human health. Air pollutants are divided into primary pollutants like carbon monoxide, sulphur dioxide, hydrocarbon species, dust and soot, which are emitted directly by air pollutant sources, and secondary pollutants like nitrogen dioxide, photochemical ozone, and aerosol, which are created by chemical changes which occur in the atmospheric environment (WHO, 2005).

After the Meuse Valley fog in 1930 (Firket, 1936) or the London smog in 1952 (Ministry of health, 1954), the air pollution is considered today an important research driver for a global public health protection (WHO, 2005). In fact a high-level exposure to these pollutants at the long-term and short-term can lead to some important adverse health effects, ranging from irritation of the respiratory system to contributing to increased prevalence and incidence of respiratory and cardiovascular diseases and premature death in people of all ages. Particularly children are very susceptible for their very fast metabolism (WHO, 2005). 
Emissions of the main air pollutants in Europe have declined significantly in recent decades, greatly reducing exposure to substances such as sulphur dioxide $\left(\mathrm{SO}_{2}\right)$ and lead $(\mathrm{Pb})$. Nevertheless, poor air quality remains an important public health issue.

Many EU Member States do not comply with legally binding air quality limits protecting human health. Exposure of vegetation to ground level ozone $\left(\mathrm{O}_{3}\right)$ will continue to exceed long-term EU objectives.

In terms of controlling emissions, only 14 European countries expect to comply with all four pollutant-specific emission ceilings set under EU and international legislation for 2010.

The upper limit for nitrogen oxides (NOx) is the most challenging 12 countries expect to exceed it, some by as much as $50 \%$ (SOER, 2010).

The Thematic Strategy on Air Pollution from the European Commission (2005) set the objectives for the improvement of human health and the environment through the improvement of air quality to the year 2020 (see table 1). At present, airborne PM, tropospheric $\mathrm{O}_{3}$, and $\mathrm{NO}_{2}$ are Europe's most problematic pollutants in terms of causing harm to health (EEA, 2010).

The main air pollutants before human's exposure are subject to a range of atmospheric processes including atmospheric transport, mixing and chemical transformation.

Air pollutants, also, depending on their physical-chemical characteristics and on the basis of factors such as atmospheric conditions or characteristics of receiving surfaces, may be deposited after either short (local, regional) or long-range (European, inter-continental) transport. Pollutants can be washed out of the atmosphere by precipitation rain, snow, fog, dew, frost and hail or deposited dry as gases or particulate matter.

\section{2. "Old" and "new" pollutants trend}

In most cities air quality has improved over the past decades. In particular, emissions of the main old air pollutants such as sulphur dioxide $\left(\mathrm{SO}_{2}\right)$ and lead $(\mathrm{Pb})$ together with other hazardous pollutants including persistent organic pollutants (POPs) and heavy metals, in Europe have declined significantly in recent decades. Nitrogen $(\mathrm{N})$ and nitrogen dioxide $\left(\mathrm{NO}_{2}\right)$, on the other hand, has not been dealt with as successfully. Between 1990 and 2008 emissions of polycyclic aromatic hydrocarbons (PAHs) decreased by $60 \%$ overall; emissions of polychlorinated biphenyls, dioxins and furans decreased too. While the majority of Countries report that emissions of these substances have fallen during that period, some Countries report that emissions have increased. Emissions of primary particulate matter, $\mathrm{PM}_{2.5}$ and PM10, have both decreased by about 13\% since 2000. At present, airborne particulate matter (PM), tropospheric (ground-level) ozone $\left(\mathrm{O}_{3}\right)$ and polycyclic aromatic hydrocarbons (PAHs) are the new problematic pollutants in Europe in terms of causing harm to health. Moreover, there is an increasing recognition of the importance of long-range hemispheric transport of air pollutants to and from Europe and other continents. VOC (Volatile Organic Compounds) and small dust particles are examples of large-scale air pollutants. At the end the wide-scale use of catalytic converters for automotive traction in 
most industrialised Countries has led, over the years, to a substantial increase in environmental concentrations of palladium, platinum, and rhodium, also known as the platinum group elements (PGEs). The detection of PGEs, even in remote areas of the planet, provides evidence of the global nature of the problem.

The following paragraphs describe the old and new contaminants in relation to their characteristics, emission sources, health effects and trends through 30 years exeperiences.

\begin{tabular}{|c|c|c|c|c|c|c|c|c|c|}
\hline \multirow{2}{*}{\begin{tabular}{|l|}
$\begin{array}{l}\text { Human } \\
\text { health }\end{array}$ \\
Pollutant
\end{tabular}} & \multicolumn{4}{|c|}{ Limit or target $\left({ }^{\circ}\right)$ value } & \multirow{2}{*}{$\begin{array}{c}\begin{array}{c}\text { Time } \\
\text { extension } \\
(\cdots)\end{array} \\
\begin{array}{c}\text { New date } \\
\text { applicable }\end{array}\end{array}$} & \multicolumn{2}{|c|}{$\begin{array}{l}\text { Long-term } \\
\text { objective }\end{array}$} & \multicolumn{2}{|c|}{$\begin{array}{c}\text { Information } \\
\left(\begin{array}{c}* \\
\text { threshold alert }\end{array}\right. \\
\text { thresholds }\end{array}$} \\
\hline & $\begin{array}{c}\text { Averaging } \\
\text { period }\end{array}$ & Value & \begin{tabular}{|c|}
$\begin{array}{c}\text { Maximum } \\
\text { number of } \\
\text { allowed } \\
\text { occurrences }\end{array}$ \\
\end{tabular} & $\begin{array}{l}\text { Date } \\
\text { applic- } \\
\text { able }\end{array}$ & & Value & Date & Period & $\begin{array}{c}\text { Threshold } \\
\text { value }\end{array}$ \\
\hline $\mathrm{SO}_{2}$ & $\begin{array}{l}\text { Hour } \\
\text { Day }\end{array}$ & $\begin{array}{l}350 \mu \mathrm{g} / \mathrm{m}^{2} \\
125 \mu \mathrm{g} / \mathrm{m}^{2} \\
\end{array}$ & \begin{tabular}{|c|}
24 \\
3 \\
\end{tabular} & $\begin{array}{l}2005 \\
2005 \\
\end{array}$ & & & & 3 hours & $500 \mu \mathrm{g} / \mathrm{m}^{2}$ \\
\hline $\mathrm{NO}_{2}$ & $\begin{array}{l}\text { Hour } \\
\text { Year } \\
\end{array}$ & $\begin{array}{l}200 \mu \mathrm{\mu g} / \mathrm{m}^{2} \\
40 \mu \mathrm{g} / \mathrm{m}^{2}\end{array}$ & $\begin{array}{c}18 \\
0 \\
\end{array}$ & $\begin{array}{l}2010 \\
2010 \\
\end{array}$ & 2015 & & & 3 hours & $400 \mu \mathrm{g} / \mathrm{m}^{2}$ \\
\hline $\begin{array}{l}\text { Benzene } \\
\left(\mathrm{C}_{g} \mathrm{H}_{s}\right)\end{array}$ & Year & $5 \mu g / m^{2}$ & 0 & 2010 & 2015 & & & & \\
\hline $\mathrm{CO}$ & $\begin{array}{l}\text { Maximum } \\
\text { daily } \\
\text { 8-hour } \\
\text { mean } \\
\end{array}$ & $10 \mathrm{mg} / \mathrm{m}^{3}$ & 0 & 2005 & & & & & \\
\hline $\mathrm{PM}_{90}$ & \begin{tabular}{|l|} 
Day \\
Year \\
\end{tabular} & \begin{tabular}{|l}
$50 \mu \mathrm{g} / \mathrm{m}^{3}$ \\
$40 \mu \mathrm{g} / \mathrm{m}^{3}$ \\
\end{tabular} & $\begin{array}{l}35 \\
0\end{array}$ & $\begin{array}{c}2005 \\
2005^{*} \\
\end{array}$ & $\begin{array}{l}2011 \\
2011 \\
\end{array}$ & & & & \\
\hline $\mathrm{PM}_{2.8}$ & Year & $\begin{array}{l}25 \mu \mathrm{g} / \mathrm{m}^{2}(\cdot) \\
20 \mu \mathrm{g} / \mathrm{m}^{2}(\mathrm{ECO})\end{array}$ & 0 & $\begin{array}{l}2010 \\
2015 \\
\end{array}$ & & $\begin{array}{l}.5 \text { to } 18 \\
\mu \mathrm{g} / \mathrm{m}^{3}\end{array}$ & 2020 & & \\
\hline $\mathrm{Pb}$ & Year & $0.5 \mathrm{mg} / \mathrm{m}^{2}\left({ }^{\circ}\right)$ & 0 & 2005 & & & & & \\
\hline As & Year & $6 \mathrm{ng} / \mathrm{m}^{2}\left({ }^{(}\right)$ & 0 & 2013 & & & & & \\
\hline $\mathrm{Cd}$ & Year & $5 \mathrm{ng} / \mathrm{m}^{2}\left({ }^{\prime}\right)$ & 0 & 2013 & & & & & \\
\hline $\mathrm{Ni}$ & Year & $20 \mathrm{ng} / \mathrm{m}^{2}(\cdot)$ & 0 & 2013 & & & & & \\
\hline $\mathrm{BaP}$ & Year & $1 \mathrm{ng} / \mathrm{m}^{2}(\cdot)$ & 0 & 2013 & & & & & \\
\hline $\mathrm{O}$, & \begin{tabular}{|l|} 
Maximum \\
daily \\
8-hour \\
mean \\
averaged \\
over \\
3 years \\
\end{tabular} & $120 \mu \mathrm{g} / \mathrm{m}^{2}\left({ }^{\prime}\right)$ & 25 & 2010 & & $\begin{array}{l}120 \\
\mu g / \mathrm{m}^{\prime}\end{array}$ & $\begin{array}{l}\text { Not } \\
\text { defined }\end{array}$ & $\begin{array}{l}1 \text { hour } \\
3 \text { hours }\end{array}$ & $\begin{array}{l}180 \mu g / \mathrm{m}^{2} \\
\left({ }^{* *}\right) \\
240 \mu g / \mathrm{m}^{2}\end{array}$ \\
\hline
\end{tabular}

Note: The majority of EU Member States (MS) have not attained the PM10 limit values required by the Air Quality Directive by 2005 (EC, 2008a). In most urban environments, exceedance of the daily mean PM10 limit is the biggest PM compliance problem. 2010 is the attainment year for $\mathrm{NO}_{2}$ and $\mathrm{C}_{6} \mathrm{H}_{6}$ limit values. A further important issue in European urban areas is also exceedance of the annual NO2 limit value, particularly at urban traffic stations.

(\#) Signifies that this is a target value and not a legally binding limit value; see EC, 2008a for definition of legal terms (Article 2).

$\left(^{*}\right)$ Exceptions are Bulgaria and Romania, where the date applicable was 2007.

(**) Signifies that this is an information threshold and not an alert threshold; see EC, 2008a for definition of legal terms (Article 2).

$(* * *)$ For countries that sought and qualified for time extension.

Source: SOER 2010.

Table 1. Summary of air-quality directive limit values, target values, assessment thresholds, long-term objectives, information thresholds and alert threshold values for the protection of human health. 


\section{Carbon monoxide (CO)}

Carbon monoxide is a tasteless, odorless, colorless and toxic gaseous pollutant ubiquitous in the outdoor atmosphere that is generated by combustion (Bell M, et All. 2009). EPA initially established NAAQS (National Ambient Air Quality Standard) for CO on April 30, 1971. The standards were set at $9 \mathrm{ppm}$, as an 8-hour average, and $35 \mathrm{ppm}$, as a 1-hour average, neither to be exceeded more than once per year. On January 28, 2011, EPA proposed to retain the existing NAAQS for carbon monoxide. After careful review of the available health science, EPA concludes that the current standards provide the required level of public health protection, including protection for people with heart disease, who are especially susceptible to health problems associated with exposures to $\mathrm{CO}$ in ambient air.

\section{Sulphur dioxide $\left(\mathrm{SO}_{2}\right)$}

Historically, $\mathrm{SO}_{2}$ derived from the combustion of fossil fuels have been the main components of air pollution in many parts of the world. The most serious problems have been experienced in large urban areas where coal has been used for domestic heating purposes, or for poorly controlled combustion in industrial installations (WHO, 2000). In recent years the use of high-sulfur coal for domestic heating has declined in many western European countries, and powder generation is now the predominant source. These changes in pattern of usage have led to urban and rural concentrations becoming similar; indeed in some areas rural concentrations now exceed those in urban areas (WHO, 2000). The city of Catania (Sicily, Italy) has established a network of air quality monitoring stations. The analysis of data show a clear and significant decline since 1993 to 2000 (First Report on the state of the environment of the City of Catania). The significant reduction in emissions of sulphur dioxide achieved since the 1970s is one of the great success stories of Europe's past air pollution policy (EEA, 2010).

\section{Particulate Matter (PM)}

Over the past decade, $20-50 \%$ of the urban population was exposed to PM10 concentrations in excess of the EU daily limit values set for the protection of human health - a daily mean of $50 \mu \mathrm{g} / \mathrm{m}^{3}$ that should not be exceeded on more than 35 days in a calendar year. The same situation happened in Siracusa (Sicily, Italy), so our research group analyzed the phisicochemical characteristics of $\mathrm{PM}_{10}$ and $\mathrm{PM}_{2,5}$ fractions in order to determine the major aerosol contributions to these two granulometric size fractions of the urban aerosol. We found that vehicular traffic is only one cause of the daily elevation of PM in Siracusa City and we exclude industrial derivation of particulate (Sciacca et al., 2007).

The Air Quality Guideline level for PM10 set by the WHO is $20 \mu \mathrm{g} / \mathrm{m}^{3}$. Exceedances of this level can be observed all over Europe, also in rural background environments. In many European urban agglomerations, PM10 concentrations have not changed since about 2000. One of the reasons is the only minor decreases in emissions from urban road traffic. Increasing vehicle-km and dieselisation of the vehicle fleet jeopardise achievements from 
other PM reduction measures. Further, in several places emissions from the industry and domestic sectors - for example, from wood burning - may even have increased slightly. The EU Air Quality Directive of 2008 includes standards for fine PM (PM2.5): a yearly limit value that has to be attained in two stages, by 1 January $2015\left(25 \mu \mathrm{g} / \mathrm{m}^{3}\right)$ and by 1 January $2020\left(20 \mu \mathrm{g} / \mathrm{m}^{3}\right)$. Further, the directive defines an average exposure indicator (AEI) for each Member State, based on measurements at urban background stations. The required and absolute reduction targets for the AEI have to be attained by 2020. Focusing on PM mass concentration limit values and exposure indicators does not address the complex physical and chemical characteristics of PM. While mass concentrations can be similar, people may be exposed to PM cocktails of very different chemical composition (WHO, 2007).

\section{Ammonia $\left(\mathrm{NH}_{3}\right)$ emission}

Ammonia has become the most abundant gas-phase alkaline species in the atmosphere. Most of the ammonia released into the atmosphere is converted into particulate ammonium sulfate and nitrate. Gaseous ammonia and ammonium compounds in particles are deposited from the air by wet deposition and dry deposition. $\mathrm{NH}_{3}$ is mainly emitted from livestock and production and application of fertilizers. Natural sources including soil, vegetation and wild animal might also be contributors to the total amount of ammonia emission.

According to the United Nations Food and Agriculture Organization recent research findings, livestock are responsible for almost two thirds of anthropogenic $\mathrm{NH}_{3}$ emissions that contribute significantly to acid rain and acidification of ecosystems (Sidiropoulos \& Tsilingiridis, 2009; EMEP/CORINAIR, 2007). Following deposition, soil microbes can convert ammonia into acidic compounds by nitrification. Through these processes, $\mathrm{NH}_{3}$ can contribute to acidic compounds on natural ecosystems and also cause eutrophication.

\section{Nitrogen oxides $\left(\mathrm{NO}_{2}\right)$}

Nitrogen dioxide a combustion-generated oxidant gas, is widely present in indoor and outdoor environments. Outdoors, where it comes primarily from high temperature fuel combustion of engines, industry, and power generation, it is a precursor to particles and ozone (G. Viegi,2004).

Using a nationwide network of monitoring sites, EPA has developed ambient air quality trends for nitrogen dioxide. Nationally, average $\mathrm{NO}_{2}$ concentrations have decreased substantially over the years. In January 2010, EPA set the primary $\mathrm{NO}_{2}$ standard at a level of 100 parts per billion and the secondary NAAQS remains to $0.053 \mathrm{ppm}$ (EPA, 2012). The European air quality guidelines suggest a daily maximum concentration of $200 \mathrm{mg} / \mathrm{m}^{3}(1 \mathrm{~h})$ for $\mathrm{NO}_{2}$, while the WHO recommends a limit of $40 \mathrm{mg} / \mathrm{m}^{3}$ (annual average) for long-term exposure. In general, the levels reported for Europe, Canada and the United States (except for New Mexico) are below this exposure threshold, whereas higher levels have been measured in Asiatic countries and in Mexico $\left(100 \mathrm{mg} / \mathrm{m}^{3}\right)$. 
There is still no robust basis for setting an annual average guideline value for $\mathrm{NO}_{2}$ through any direct toxic effect. Evidence has emerged, however, that increases the concern over health effects associated with outdoor air pollution mixtures that include $\mathrm{NO}_{2}$. A number of recently published studies have demonstrated that $\mathrm{NO}_{2}$ can have a higher spatial variation than other traffic-related air pollutants, for example, particle mass. These studies also found adverse effects on the health of children living in metropolitan areas characterized by higher levels of $\mathrm{NO}_{2}$ even in cases where the overall city-wide $\mathrm{NO}_{2}$ level was fairly low. A number of short-term experimental human toxicology studies have reported acute health effects following exposure to 1-hour $\mathrm{NO}_{2}$ concentrations in excess of $500 \mu \mathrm{g} / \mathrm{m}^{3}$. Although the lowest level of $\mathrm{NO}_{2}$ exposure to show a direct effect on pulmonary function in asthmatics in more than one laboratory is $560 \mu \mathrm{g} / \mathrm{m}^{3}$, studies of bronchial responsiveness among asthmatics suggest an increase in responsiveness at levels upwards from $200 \mu \mathrm{g} / \mathrm{m}^{3}$.

Since the existing WHO AQG short-term $\mathrm{NO}_{2}$ guideline value of $200 \mu \mathrm{g} / \mathrm{m}^{3}$ (1-hour) has not been challenged by more recent studies, it is retained. In conclusion, the guideline values for $\mathrm{NO}_{2}$ remain unchanged in comparison to the existing WHO AQG levels, i.e. $40 \mu \mathrm{g} / \mathrm{m}^{3}$ for annual mean and $200 \mu \mathrm{g} / \mathrm{m}^{3}$ for 1-hour mean.

\section{Ozone $\left(\mathrm{O}_{3}\right)$}

It is the principal component of smog, which is caused primarily by automobile emissions, predominantly in urban areas. Normal levels of ozone in the air are between 20 and 80 $\mathrm{mg} / \mathrm{m}^{3}$. Ozone concentrations in urban areas rise in the morning, peak in the afternoon, and decrease at night. Ozone has become a significant pollutant as a result of increased population growth, industrial activities, and use of the automobile. Ozone is at present the primary air pollution problem in the United States. A trend analysis covering the years from 1993 to 2005 showed that the average number of hours with an ozone concentration above $180 \mu \mathrm{g} / \mathrm{m}^{3}$ (the EU information threshold) for any given monitoring site was higher in the summer of 2003 than in any of the previous years (Park JW et al., 2004). On the February 2002 European Parliament approved a guideline (2002/3/CE) that indicates the "information threshold" $\left(180 \mu \mathrm{g} / \mathrm{m}^{3}\right)$ and "alert threshold" $\left(360 \mu \mathrm{g} / \mathrm{m}^{3}\right)$ for ozone and imposes urgent obbligation of the population's information. In Italy, legislative decree 155/2010 sets long term aims for human health protection $\left(120 \mu \mathrm{g} / \mathrm{m}^{3}\right.$ during 8 hours). Ozone is monitored in Catania (Sicily, Italy) since 1997 by two control units but since then attention levels for this compound have never been exceeded (Comune di Catania, 2001). Respiratory tract responses induced by ozone include reduction in lung function, aggravation of preexisting respiratory disease (such as asthma), increased daily hospital admissions and emergency department visits for respiratory causes, and excess mortality (Corsmeier et al., 2002). Controlled human exposure studies have demonstrated that short-term exposure - up to 8 hours - causes lung function decrements such as reductions in forced expiratory volume in one second (FEV1), and the following respiratory symptoms: cough, throat irritation, pain, burning, or discomfort in the chest when taking a deep breath, chest tightness, wheezing, or shortness of breath. The effects are reversible, with improvement and recovery to baseline varying from a few hours to 48 hours after an elevated ozone exposure. 


\section{Heavy metals}

Heavy metals are a class of pollutants extremely widespread in the various environmental matrices. They are natural components of the earth's crust. Their presence in air, water and soil erosion resulting from natural phenomena and human activities. To a small extent they enter human bodies where, as trace elements, they are essential to maintain the normal metabolic reactions. They cannot be degraded or destroyed, and can be transported by air, and enter water and human food supply. Respect to air pollution, the metals that are generally more concerned are: $\mathrm{As}, \mathrm{Cd}, \mathrm{Co}, \mathrm{Cr}, \mathrm{Mn}, \mathrm{Ni}, \mathrm{Pb}$ as conveyed by particulate air pollution. Their origin is different: $\mathrm{Cd}, \mathrm{Cr}$ and $\mathrm{As}$ are mostly from mining and steel industries; $\mathrm{Cu}$ and $\mathrm{Ni}$ from combustion processes; $\mathrm{Co}, \mathrm{Cu}, \mathrm{Zn}$ and $\mathrm{Cr}$ from cementitious materials obtained by recycling scrap steel industries and incinerators. The effect of heavy metals on the human health depends on the mode of assumption, as well as the amount absorbed. Heavy metals (such as cadmium, mercury and lead) are recognised as being directly toxic to biota. All have the quality of being progressively accumulated higher up the food chain, such that chronic exposure of lower organisms to much lower concentrations can expose predatory organisms, including humans, to potentially harmful concentrations. In humans they are also of concern for human health because of their toxicity, their potential to cause cancer and their ability to cause harmful effects at low concentrations. Their relative toxic/carcinogenic potencies are compound specific. Specifically, exposure to heavy metals has been linked with developmental retardation, various cancers, kidney damage, and even death in some instances of exposure to very high concentrations. Heavy metals can reside in or be attached to PM. For several metals there are the standard reference, in particular for lead the limit is intended as an average annual value of $0.5 \mathrm{ug} / \mathrm{m}^{3}$.

Urban sources of lead are fossil fuels, mining and manufacturing. The use of lead as an additive to gasoline was banned in 1996 in the United States and since then the cases of acute intoxication are notably decreased. In the Municipality of Catania lead is measured through control programmes long for 15- 20 days. Since 1999 to 2000 it can be note a decrease of mean concentrations (from $0,38 \mu \mathrm{g} / \mathrm{m}^{3}$ to $0,15 \mu \mathrm{g} / \mathrm{m}^{3}$ ) with values lower than those required in the European Rule 99/30/CE. This result is correlated with the abolishment of use of lead in gasoline (Comune di Catania, 2001).

In our experience high-level exposure to metals of men can damage sperm production and motility, as are suggest by an our study that shows adverse impact of heavy metals on male reproductive health. We have conducted a case-control study to investigate the exposition to lead, arsenic, nickel and male fertility. The results show a sperm motility reduction of $50 \%$ (Ferrante $\mathrm{M}$ et al., 2011). Another study in the industrial triangle of Priolo-Melilli-Augusta shows that males living in these towns show a sperm progressive motility decrease from $45 \%$ to $23 \%$ whereas density and morphology were into the reference limit of WHO parameters (Ferrante M et al., 2011).

Cadmium is widely spread in the environment. Its consumption is growing, as a result cadmium contamination of soil, water and air increases. Cadmium enters soil, water, and air 
from mining, industry, and burning coal and household wastes and its particles in air can travel long distances before falling to the ground or water. Cadmium is accumulated in fish, plants, animal and human body. People can be exposed to cadmium eating contaminated foods, smoking cigarettes or breathing cigarette smoke, drinking contaminated water, living or working near industrial facilities which release cadmium into the air. Following the European Law 155/2010, Sicily adopted a plane to value and manage air quality, aiming to not exceed levels of $5,0 \mathrm{ng} / \mathrm{m}^{3}$ of cadmium in the air (ARPA Sicilia). The form of cadmium that is of most interest for health effects from inhalation exposure is cadmium oxide because that is the main form of airborne cadmium. Our research group has conducted a casecontrol study to examine relationships between environmental exposures, particularly to $\mathrm{Cd}$, and male infertility. Cd showed concentrations in seminal plasma of the cases $(1.67 \mu \mathrm{g} / \mathrm{l})$ higher than controls $(0.55 \mu \mathrm{g} / \mathrm{l})$ and cases showed a motility reduction from $45 \%$ to $23 \%$ (50\% reduction). Our results indicate that the males exposed to environmental Cd showed a deleterious effect on fertility (Ferrante M et al., 2011). Another study, carried out also by our research group and not yet published, has shown the toxic effect of Cd even on male reproductive organs because this metal cause a blood-testis barrier disruption and consequently an impairment in sperm production. Finally we have to consider the effect of cadmium on cancer development. $\mathrm{Cd}$ was classified as a cancer-causing agent in humans by the WHO (1993), based on consistent reports of an association between Cd exposure and lung cancer (ATSDR 2008).

Heavy metals can reside in or be attached to PM.

\section{Organic compound}

\subsection{Persistent Organic Pollutants (POPs)}

Persistent organic pollutants are a group of chemicals which have been intentionally or inadvertently produced and introduced into the environment and because of theirs resistance to degradation, they persist in the environment.

Due to their stability and transport properties, they are now widely distributed around the world, and are even found in places where they had never been used, such as the arctic regions. Given their long half-lives and their fat solubility, POPs tend to bioaccumulate in the food-chain including fish, meat, eggs and milk. POPs are also present in the human body and traces can be found in human milk (WHO, 2007).

The United Nations Environment Programme Governing Council (GC) originally created a have listed 12 POPs, known as the "dirty dozen." Nine of these are old organochlorine pesticides, including including aldrin, dichlorodiphenyltrichloroethane (DDT), chlordane, dieldrin, endrin, heptachlor, hexachlorobenzene, mirex and toxaphene, whose production and use have been banned or strictly regulated by most countries for some time. In addition other three POPs of concern are industrial chemicals, including the widely used polychlorinated biphenyls (PCBs) as well as two groups of industrial by-products, 
polychlorinated dibenzodioxins (PCDDs or dioxin) and polychlorinated dibenzofurans (PCDFs or furans). In recent years, this list has been expanded to include polycyclic aromatic hydrocarbons (PAHs), polybrominated diphenyl ethers (PBDE), and tributyltin (TBT). The groups of compounds that make up POPs are also classed as persistent, bioaccumulative, and toxic (PBTs) or toxic organic micro pollutants (TOMPs). These terms are essentially synonyms for POPs (Crinnion, 2011).

While production of PCBs has been largely banned for many years, the electrical transformers and other equipment containing still these chemicals are still in use and they present, today, serious disposal problems.

Regard to PCDDs and PCDFs, the better manufacturing controls and reduction of emissions from industrial combustion processes, e.g. power generation and waste incineration plants, have made a measurable impact on decreasing levels of these chemicals in human milk, particularly in Europe (WHO, 2007).

Humans can be exposed to POPs through the direct exposure, e.g. occupational accidents or by environment exposure (including indoor). Short-term exposures to high concentrations of POPs may result in severe illness and death. Chronic exposure to POPs may also be associated with a wide range of adverse health effect as a the endocrine disruption, reproductive and immune dysfunction, neurobehavioral and developmental disorders and cancer (Ritter et al, 1995).

Polycyclic Aromatic Hydrocarbons (PAHs) and PCDD/Fs are perhaps the most obvious example. However, because an extensive array of POPs occur and accumulate simultaneously in biota it is very difficult to say conclusively that an effect is due to one particular chemical or a family of chemicals, in fact several chemicals act synergistically (Jones, 1999).

\subsection{Dioxins and furans (PCDDs and PCDFs)}

Polychlorinated dibenzo-p-dioxins and dibenzofurans are two similar classes of chlorinated aromatic chemicals that are produced as contaminants or by products.

Most dioxins and furans are not man-made or produced intentionally, but are created when other chemicals or products are made. They are formed as unwanted byproducts of certain chemical processes during the manufacture of chlorinated intermediates and in the combustion of chlorinated materials. The chlorinated precursors include polychlorinated biphenyls (PCB), polychlorinated phenols, and polyvinyl chloride (PVC) (Faroon M. et. al., 2003). Of all of the dioxins and furans, one, 2,3,7,8-tetrachloro-p-dibenzo-dioxin (2,3,7,8 TCDD) is considered the most toxicand the most extensively studied. Like the other POPs are chemically stable and highly lipophilic; in the environment, are persistent, undergo transport, and preferentially bioconcentrate in higher trophic levels of the food chain (Safe $\mathrm{SH}, 1998)$. In terms of dioxin release into the environment, uncontrolled waste incinerators (solid waste and hospital waste) are often the worst culprits, due to incomplete burning. 
Technology is available that allows for controlled waste incineration with low emissions. Dioxins also have been detected at low concentrations in cigarette smoke, home-heating systems, and exhaust from cars running on leaded gasoline or unleaded gasoline, and diesel fuel. The larger particles will be deposited close to the emission source, while very small particles may be transported longer distances will be deposited on land or water, contaminating the food of animal origin, as they are persistent in the environment and accumulate in animal fat and finding himself well in dairy, meat, fish and shellfish (Alcock $R$, 2003). Excluding occupational or accidental exposures the most common way is by eating food contaminated with dioxins particularly important is, also, the exposure of infants through breast-feeding because of the high content of fat in human milk and may exceed the exposure of adults by one or two orders of magnitude (Gies A, 2007).

Releases from industrial sources have decreased approximately $80 \%$ since the 1980 s (Consonni, 2012) and have been the subject of a number of federal and state regulations and clean-up actions; however, current exposures levels still remain a concern. (EPA, http://www.epa.gov/pbt/pubs/dioxins.htm). TDI (tolerable daily intake) values recommended by WHO is $1-4 \mathrm{pg}$ TEQ/kg/day. However, several nations have performed their own reassessment of the available toxicity data for dioxin to derive a TDI (ASTDR, 2011). Today, the largest release of these chemicals occurs as a result of the open burning of house- hold and municipal trash, landfill fires, and agricultural and forest fires. Breast milk is a substantial source of exposure for infants (Lundqvist et al., 2006), though breast milk levels have been decreasing in recent years (Arisawa et al., 2005).

\subsection{Polycyclic AromaticH (PAHs)}

Polycyclic aromatic hydrocarbons are ubiquitous pollutants formed from the combustion of fossil fuels, industrial powder generation, incineration, production of asphalt, coal tar and coke, petroleum catalytic cracking and primary aluminium production (WHO, 2003). The specific emissions of PAHs from modern cars were observed to be 5 times higher from diesel engines than from gasoline cars during transient driving conditions. Older diesel cars and gasoline cars with a catalytic converter of outmoded design have 5-10 times higher PAH emissions than modern cars. PAHs can react with pollutants such as ozone, nitrogen oxides and sulfur dioxide, yielding diones, nitro- and dinitro-PAHs, and sulfonic acids, respectively (WHO, 2000). PAHs have a tendency to be associated with particulate matter and may be subject to direct photolysis (WHO, 2010). A number of PAHs are mutagenic and genotoxic, and induce DNA adduct formation in vitro and in vivo. IARC considers several purified PAHs and PAH derivatives to be probable (group 2A) or possible (group 2B) human carcinogens. Benzo[a]Pyrene has decreased fertility and caused embryotoxicity (WHO 2010) Our research group has conducted a study aimed to evaluate concentration of priority PHAs in seminal plasma samples of healthy men (age 20-45 years) living in a polluted area of Sicily (Priolo-Augusta-Melilli triangle), declarated "area at elevated environmental crisis". Our results show that the semen quality could not be affect by PAHs concentration air (Oliveri Conti et al., 2011). 
Emissions of PAHs decreased by $60 \%$ overall between 1990 and 2008 in the EEA-32 but increased in a small number of countries (EEA 2010). In Europe and the United States, urban traffic contributes $46-90 \%$ of the total PAHs in ambient air. Recent initiatives included the conversion to ultralow-sulfur diesel fuel, aimed to be $97 \%$ cleaner (Narváez, 2008)

\subsection{Non-Methane Volatile Organic Compounds (NMVOCs or TNMHC)}

Non-methane volatile organic compounds are a collection of organic compounds that differ widely in their chemical composition but display similar behaviour in the atmosphere. Essentially, NMVOCs are identical to VOCs, but with methane excluded. NMVOCs are emitted into the atmosphere from a large number of sources including combustion activities, paint application, road transport, dry-cleaning and other solvent uses and production processes. NMVOCs contribute to the formation of ground level (tropospheric) ozone. In fact, the hydrocarbons have a strong tendency to react, in the presence of light, with the oxides of nitrogen and oxygen. In addition, certain NMVOC species or species groups such as benzene and 1,3 butadiene are hazardous to human health. Quantifying the emissions of total NMVOCs provides an indicator of the emission trends of the most hazardous NMVOCs. Biogenic NMVOCs are emitted by vegetation, with amounts dependent on the species and on temperature (EEA, 2010; EEA, 2011). There are thousands of organic compounds known ascribable to NMVOC, both of natural origin that is released into the air from plants (biogenic), and anthropogenic (anthropogenic), both species we can find them in the air or in the form of gas or in the form steam. The main TNMCH are generally: aliphatic hydrocarbons or carbon chain with a linear structure, or with aromatic ring structure (benzene, toluene, xylenes, etc..), oxygenated (aldehydes, ketones, etc.)., etc. Their concentration in the atmosphere in urban areas and industrial centers are directly related to vehicular traffic, domestic heating, to phenomena of evaporation of gasoline (engine compartments and tanks), the exhaust gas vehicle (incomplete combustion of fuels), the emissions from petrol stations fuel and many industrial activities (eg, oil refining, storage and handling of fuels, production of paints and solvents, etc. ...) (ARPAT, 2010; Broderick \& Marnane, 2002). Solvent use and road transport are the two most significant sources of NMVOC emissions in urban environments. (Sidiropoulos C, 2009) but Today the major contributions of NMVOCs anthropogenic emissions are ascribed primarily to vehicular traffic. Adverse operating conditions of the vehicle (low speed, repeated gear changes, and frequent stops to a minimum) as those due to heavy traffic have resulted in greater emission of unburned hydrocarbons. The evaporative emissions mainly stem from the volatility of fuel and are therefore made up only of hydrocarbons. They occur when walking, both with the engine off at stops (ARPAV, 2004). The effects on human health are very different depending on the types of compounds present in the mixture thus depend solely on the type of hydrocarbons present and their concentrations (WHO, 1989; WHO, 2005). Hydrocarbons Alkanes are absolutely non-toxic. Are toxic and carcinogenic in some cases a part of the aromatic hydrocarbons ("Air Quality Guideline for Europe" WHO, 1989; Sciacca S. \& Oliveri Conti G, 2009). 


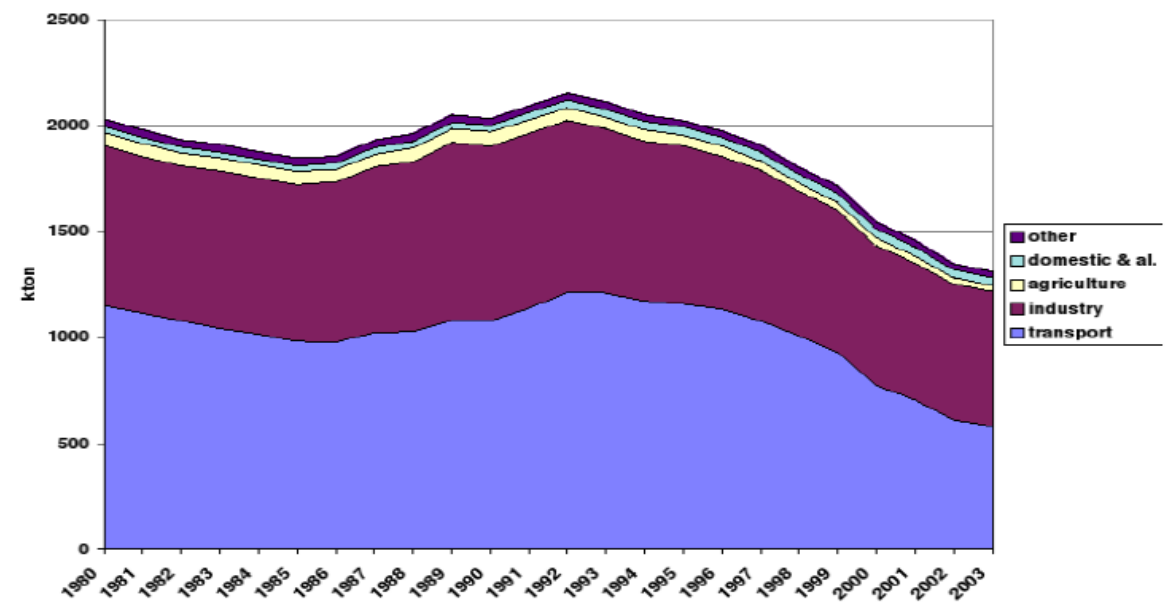

Figure 1. TNMCH Anthropogenic emission in Italy (da APAT)

Improved loading technology in the oil industry in the last 10 years has contributed to the decline, and this trend continued in 2010. However, the emission of solvents from products increased steeply in 2010, after a drop in the previous year, and made up for the decline in the oil industry. The NMVOC emission still ended $28 \%$ below the Gothenburg Protocol target. The emissions of non-methane volatile organic compounds have decreased by $51 \%$ since 1990. In 2009, the most significant sources of NMVOC emissions were 'Solvent and product use' (36\%) (comprising activities such as paint application, dry-cleaning and other use of solvents), followed by 'Commercial, institutional and households' (15\%). The decline in emissions since 1990 has primarily been due to reductions achieved in the road transport sector due to the introduction of vehicle catalytic converters and carbon canisters on petrol cars, for evaporative emission control driven by tighter vehicle emission standards, combined with limits on the maximum volatility of petrol that can be sold in EU Member States, as specified in fuel quality directives. The reductions in NMVOC emissions have been enhanced by the switching from petrol to diesel cars in some EU countries, and changes in the 'Solvents and product use' sector (a result of the introduction of legislative measures limiting for example the use and emissions of solvents.

\subsection{Polychlorinated biphenyls (PCBs)}

Polychlorinated biphenyls are mixtures of chlorinated hydrocarbons that have been used extensively since 1930 in a variety of industrial uses and are another major contaminant of concern in communities (Johnson BL, 1999). PCB production in most countries was banned in the 1970s and 1980s (Vallack, 1998).

According to the position of the chlorine atoms in the molecule of biphenyl may be obtained 209 congeners, 12 of which have characteristics similar to the dioxins and therefore defined dioxin-like (ASTDR, 2000). All PCB congeners are lipophilic (lipophilicity increases with 
increasing degree of chlorination) and have very low water solubilities. Once in the environment, PCBs do not readily break down and therefore may remain for very long periods of time. They can easily cycle between air, water, and soil and can be carried long distances. Air is probably the most significant compartment for environmental distribution. Their presence is ubiquitous in the environment, and residues have even been detected in the Arctic air, water and organisms (Alcock et al, 2003).

PCBs were formerly used as dielectric fluids in transformers and large capacitors, as pesticide extenders, plasticisers in sealants, as heat exchange fluids, hydraulic lubricants, cutting oils, flame retardants, dedusting agents, and in plastics, paints, adhesives and carbonless copy paper. Although PCBs are no longer made people can still be exposed to them. Old fluorescent lighting fixtures and old electrical devices and appliances, such as television sets and refrigerators, therefore may contain PCBs if they were made before PCB use was stopped. When these electric devices get hot during operation, small amounts of PCBs may get into the air and raise the level of PCBs in indoor air (ASTDR, 2000).

Food is the main source of exposure for the general population. PCBs enter the food chain by a variety of routes, including migration into food from external sources, contamination of animal feeds, and accumulation in the fatty tissues of animals. PCBs are found at higher concentrations in fatty foods (e.g., dairy products and fish). Other sources of exposure in the general population include the release of these chemicals from PCB-containing waste sites and from fires involving transformers and capacitors. The transfer of PCBs from mother to infant via breast milk is another important source of exposure. The lesser-chlorinated PCBs are more volatile and indoor inhalational exposure from buildings containing caulking made with these PCBs prior to 1979 can increase background serum levels.

Today, PCBs can still be released into the environment from poorly maintained hazardous waste sites that contain PCBs; illegal or improper dumping of PCB wastes, such as old transformer fluids; leaks or releases from electrical transformers containing PCBs; and disposal of PCB-containing consumer products into municipal or other landfills not designed to handle hazardous waste. PCBs may be released into the environment by the burning of some wastes in municipal and industrial incinerators (ASTDR, 2000).

Human health effects that have been reported after investigations of occupational and accidental exposures to high levels of PCBs include elevations of serum hepatic enzymes, dermal changes (such as chloracne and rashes), inconsistent associations with serum lipid levels, and some types of cancer in particular of the gastrointestinal tract (e.g., liver, biliary). They are classified as probable human carcinogens by IARC (ATSDR, 2000; Carpenter, 2006). PCBs weakly interact with estrogen and thyroid receptors and with transport proteins (Purkey et al., 2004). Developmental and fetotoxic effects may also be observed in humans.

Our research group has conducted a study with the aim to evaluate the presence of possible alterations of sperm parameters of male exposed to PCB. We studied a group of 96 volunteers (aged 20-46 years) resident in the Priolo-Augusta-Melilli (SR) triangle, which has been declared "area at elevated environmental crisis" (Italian Government note). Of all 
congeners analyzed the 74 appears to be the predominant (Fig.1). Our results show an alteration of the morphology and motility of spermatozoa. (Ferrante et al., 2006; Altomare et al, 2012).

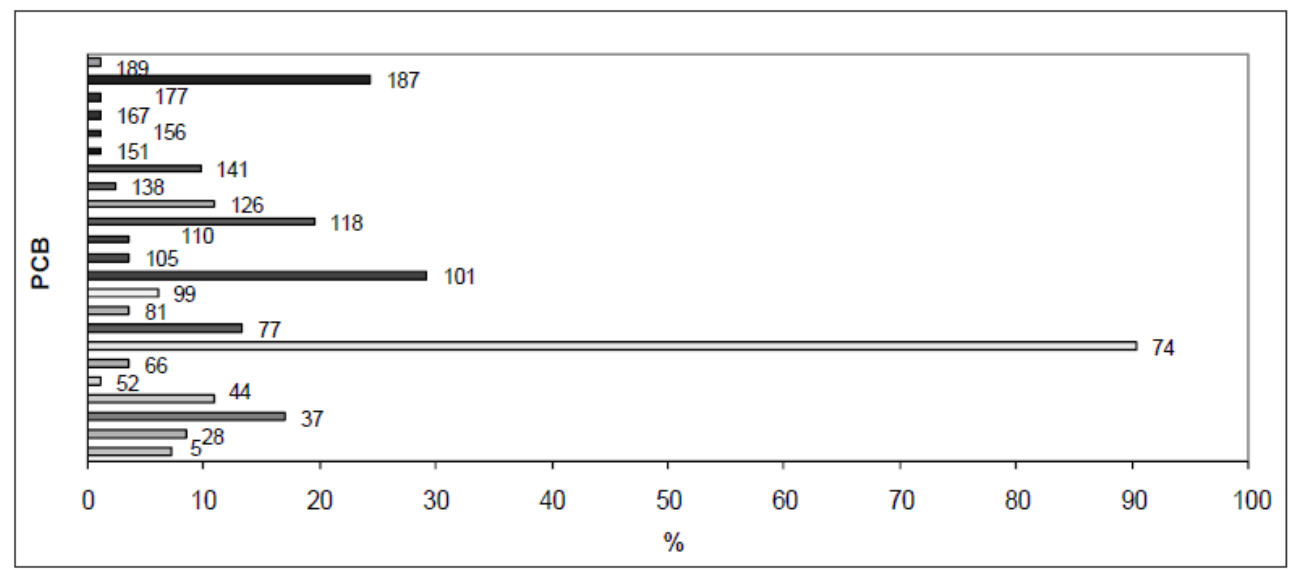

Figure 2. Percentage of subjects with detectable PCB levels in seminal plasma.

In general, published emission estimates for PCBs are difficult to compare as the methodological and empirical basis are different (Breivik et al., 2002; Breivik et al., 2004).

For decades, many countries and intergovernmental organizations have banned or severely restricted the production, usage, handling, transport and disposal of PCBs so, since the early 1980s, PCB concentrations in the air have shown a significantly decreasing trend for urban, rural, and marine/coastal areas. PCBs are also significantly decreased the concentrations in blood and human milk (Porta et al, 2012; Alivernini et al, 2011).

Concentrations of PCB in human blood decreased about 34-56\% from 2002 to 2006 with difference for age, body mass index, weight (Porta et al., 2012). The comparison between PCBs measured in human milk samples collected in Rome between 2005 and 2007 with two previous studies performed in Rome in 1984 and in 2000-2001 indicates a 64\% decrease of PCB levels, still in progress data are in good agreement with recent European studies (Alivernini et al., 2011).

\subsection{Volatile Organic Compounds (VOCs)}

Volatile organic compounds, major air pollutants in the indoor environment, are molecules typically containing 1-18 carbon atoms that readily volatilize from the solid or liquid state and are easily released into indoor air. All organic chemical compounds that can volatize under normal indoor atmospheric conditions of temperature and pressure are VOCs. These substances are classified in Very Volatile Organic Compound (VVOC), Volatile Organic Compound (VOC), and semivolatile Organic Compound (SVOC) to show the wide range of volatility among organic compounds. VOCs are emitted from many household products, 
including paints and lacquers, paint strippers, cleaning supplies, combustion appliances, aerosol sprays, glues, adhesives, dry-cleaned clothing, and environmental tobacco smoke. VOCs, which predominantly exist in the vapor phase in the atmosphere, and SVOCs, which exist in both vapor and condensed phase, redistribute to indoor surfaces and may persist from several months to years (Weschler et al., 2008). VOCs are of concern as both indoor air pollutants and as outdoor air pollutants but several studies have reported a two to fivefold increase in indoor concentrations of VOCs as compared to outdoors (Sexton et al. 2004). VOCs emission in Italy are regulated by the legislative decree 152/2006 that establishes thereshold values between $50 \mathrm{mg} \mathrm{C} / \mathrm{Nm}^{3}-150 \mathrm{mg} \mathrm{C} / \mathrm{Nm}^{3}$. Moreover both adults and children spend an estimated $90 \%$ of daily hours in indoor setting and energy conservation measures for buildings have led to reduced air exchange rates and promotion of indoor moisture buildup (Bornehag CG et al. 2005).

Exposure to VOCs can lead to acute and chronic health effects. The risk of health effects from inhaling any chemical depends on how much is in the air, how long and how often a person breathes it in (MDH, 2010). The major potential health effects include acute and chronic respiratory effects, such as bronchitis and dyspnea. Over the past few decades concern has increased about respiratory health effects from exposure to indoor air pollution.

Several studies have shown that the major effect of VOC's exposure is the development of asthma and allergic symptoms. Global trend in prevalence of allergic airway disease and other types of allergies in children and young adults appears to be increasing in Western countries, not only as seasonal decreases or in the context of particular ambients (Green et al., 2003). Between 2008 and 2010, our research group has conducted a study to evaluate the exposure to VOCs of secondary school students of first and second degree of Melilli Augusta and Priolo, area whit high environmental impact. The exposition was assessed by the passive samplers know, the Radiello, worn by student. The results show that the concentrations of major VOCs such as benzene, toluene and ethylbenzene, with a few exceptions, are within the limits of the law (Acerbi et al, 2010). Another study of our Department shows that the exposure to various environmental pollutants, including VOC, can cause development and exacerbation of asthma symptoms especially in children (Oliveri Conti G et a.,1 2011). Causal factors underlying these diseases and other contributors of global trend in prevalence since the 1970s remain unknown. Global secular trend in asthma and the allergy disease prevalence draw a parallel with vast shift in diet, lifestyle, and consumer product uses within the western societies since the World War II (Weschler et al., 2009). Enormous quantity and array of chemical compounds have been introduced in the societies which adopted western lifestyles. Consumer products, such as computer, TV, and synthetic building materials, including artificial carpets, composite wood, polyvinyl chloride (PVC) flooring, foam cushions, and PVC pipes emit an array of volatile organic compounds (VOCs), semi-volatile organic compounds (sVOCs) and nonorganic compounds. In a study, conducted as part of the European Community Respiratory Health Survey (ECRHS), authors reported higher concentration of total VOCs in recently painted homes, which was significantly associated with increased odds of asthma. Similarly, in a 
recent population based case-control study of children in Western Australia, two to threefold increased odds of asthma was reported among children exposed to benzene, ethylbenzene, and toluene (Rumchev et al., 2004). Indoor residential chemicals, emitted from particle board, plastic materials, recent painting, home cleaning agents, air freshener, pesticide, and insecticide, consistently increase the risks of multiple allergic symptoms and asthma-like symptoms (Henderson et al., 2008; Mendell et al ., 2007). As far as respiratory deseases, VOCs are responsible for allergic skin reaction, neurological toxicity, lung cancer, and eye and throat irritation, fatigue, headaches, dizziness, nausea and neurological symptoms such as lethargy and depression (Guo et al., 2004).

One of the most important VOCs is benzene. Benzene is an aromatic volatile hydrocarbon, having a characteristic smell. It come mainly into air from vehicles emissions, and from refueling losses; smoke from tobacco contains benzene and, in closed spaces, it constitutes the greater source of such polluter. Short term effects on man act on nervous system while long term ones produce progressive reduction of blood plateles and effect on leucocytes. Due to its toxicity benzene has been inserted from IARC in group I. In an our study as far as the city Catania is concerned, the benzene concentration has been maintained under the objective values of $10 \mathrm{microgrammi} / \mathrm{m}^{3}$ (Ferrante et al., 2004)

We made a critical analysis of recent literature on biomarkers used in the assessment of exposure to benzene in order to identify, on the basis of personal research, and reliable biological indicators appropriate for monitoring exposure to low levels of solvent. We concluded identifying the urinary compartment, the site of elimination of benzene and its metabolites as such, as the most suitable for biological monitoring of benzene. The urinary benzene is certainly a valid biomarkers in the estimation of the internal dose of benzene, even if the measure prevail in precautions. The trans, trans-muconic acid, metabolite of benzene, as there is of toxicological interest, can be considered the most important biomarker in the assessment and of exposure and individual susceptibility to adverse effects of benzene. (Vivoli et al., 2002)

\section{Platinum Group Elements (PGEs or PGMs)}

The platinum group metals sometimes referred as the platinum group elements, comprise the rare metals platinum $(\mathrm{Pt})$, palladium $(\mathrm{Pd})$, rhodium $(\mathrm{Rh})$, ruthenium $(\mathrm{Ru})$, iridium $(\mathrm{Ir})$ and osmium (Os).

Accumulation of PGEs is increasing in the environment over the time. The detection of PGEs, even in remote areas of the planet, provides evidence of the global nature of the problem. Catalytic converters of modern vehicles are considered to be the main sources of PGE contamination in addition to some other application (e.g. industrial, jewelry, anticancer drugs, etc.). The wide-scale use of catalytic converters for automotive traction in most industrialised Countries has led, over the years, to a substantial increase in environmental concentrations of PGEs. Along with PGEs the vehicle exhaust catalysts contain also a number of stabilizers, commonly oxides of rare earth elements and alkaline earth elements 
such as cerium (Ce), lantanium (La) and zirconium (Zr). Platinum content of road dusts, however, can be soluble, consequently, it enters to the waters, sediments, soil, and finally, the food chain. The effect of chronic occupational exposure to Pt compounds is welldocumented, and certain Pt species are known to exhibit allergenic potential, but PGEs have also been found to be related to asthma, nausea, increased hair loss, increased spontaneous abortion, dermatitis, and other serious health problems in humans. Some researchers have shown that the $\mathrm{Rh}$ and $\mathrm{Pd}$ have a role on the emergence of certain tumors of the blood in rat. The vast majority of studies on airborne PGMs have however been carried out in urban areas characterised by high traffic density or in areas adjoining the aforementioned zones.

Analytical difficulties restrict the number of studies carried out for PGE concentration estimation in air and airborne particles.

In fact the low PGE concentration in the environmental samples combined with numerous interferences in the most sensitive analytical techniques are considered to be the major difficulties by many technicians.

Ravindra et al. (2004) says that : "the Pt concentration in air was reported to be lower than $0.05 \mathrm{pg} / \mathrm{m}^{3}$ near a freeway in California. However, other studies in Germany have shown that the total $\mathrm{Pt}$ concentration in air along a highway ranged from 0.02 to 5.1 $\mathrm{pg} / \mathrm{m}^{3}$ (0.6 to $130 \mathrm{ng} / \mathrm{g}$ ) with the Pt mainly present in the small particle size fraction (from 0.5 to $8 \mu \mathrm{m}$ ), whilst the larger airborne particles had a lower Pt content. The proportion of soluble platinum in air particles varied from $30 \%$ to $43 \%$. A mean Pt concentration of $7.3 \mathrm{pg} / \mathrm{m}^{3}$ has been measured inside Munich city buses and tramways during regular rides, with a strong correlation with traffic density. Bocca et al. (2003) reported a significant difference for the PGE content of air in urban and remote sites of Rome. The PGE concentration in urban airborne particulate matter ranged at 21.2-85.7 $\mathrm{pg} / \mathrm{m}^{3}$ for $\mathrm{Pd}$, 7.8-38.8 pg/m $\mathrm{m}^{3}$ for $\mathrm{Pt}$, and 2.2-5.8 pg/m $/ \mathrm{m}^{3}$ for $\mathrm{Rh}$. In Madrid, the Pt and $\mathrm{Rh}$ concentrations in airborne particulate matter ranged from 3.1 to $15.5 \mathrm{pg} / \mathrm{m}^{3}$, and from not detectable to $9.32 \mathrm{pg} / \mathrm{m}^{3}$, respectively".

The present literature survey shows that the concentrations of these metals have increased significantly in the last decades in diverse environmental matrices; like airborne particulate matter, soil, roadside dust and vegetation, river, coastal and oceanic environment. Generally, PGEs are referred to behave in an inert manner and to be immobile.

Our research group has carried out a study on this issue entitled: "First data about $\mathrm{Pt}, \mathrm{Pd}$, and Rh in air, foods and biological samples in the district of Catania" (Ferrante et al., 1998) in order to acquire data about $\mathrm{Rh}, \mathrm{Pt}$ and $\mathrm{Pd}$ concentrations in air, food, blood and urine samples of the territory of Catania in order to establish a set of values to make an initial bibliography. Metals investigated have been found in the samples assayed, although discontinuously and in trace concentrations.

Another study carried out on the Italian territory by Spaziani et al. (2008) investigated the Pt distribution in urban matrices (soils and dusts) in five cities, from north (Padova), central 
(Rome and Viterbo), and south (Naples and Palermo) Italy in order to obtain a large set of data concerning pollution from autocatalysts. Analyses show a beginning of Pt enrichment in urban soils, with concentration ranges of 0.1-5.7 ng/g (Padova), 7-19.4 ng/g (Rome), 4.920 ng/g (Viterbo), 4.7-14.3 ng/g (Napoli), and 0.2-3.9 ng/g (Palermo).

Platinum group elements from automotive catalytic converters are continuously increasing in environmental matrices over the time. It is still under discussion, whether the emitted PGEs are toxic for human beings. The potential health risk from these elements would have to be taken in consideration for the possible risk of exposure for those living in urban environments, or along major highways.

\section{Conclusion}

The movement of atmospheric pollution between continents attracts increasing political attention. In a context dominated by the struggle against the emission of greenhouse gases, problems of air quality should not be underestimated and policies relating to climate protection must be taken into account.

All the above topics need further investigation (both experimental and model), partly on the base of health studies for novel air pollutants, to reach a better understanding of the behaviour of these in the environment. Greater international cooperation, also focusing on links between climate and air pollution policies, is required more than ever to address the phenomenon of air pollution.

However, the most important thing that emerges from our forty years of experience on the environmental topics is the need for a more precise and careful risk management (identification, esteem, evaluation and interventions on the risk). Too often technologies that pose a serious risk to the human health are replaced with technology just as risky or even riskier for the health of the population with enormous burdens also of the social and health costs.

\section{Author details}

Margherita Ferrante, Maria Fiore, Gea Oliveri Conti, Caterina Ledda, Roberto Fallico and Salvatore Sciacca

Department "G.F. Ingrassia", Sector of Hygiene and Public Health, Catania University, Italy

\section{References}

Acerbi G, Zuccarello M, Toscano, Cipresso R, Mazzarino A, Bandini L, Ferrante M, Sciacca S. Valutazione dell'esposizione ai COV negli studenti delle scuole di Augusta-PrioloMelilli, Congresso nazionale SiTI ottobre 2010. 
Agency for Toxic Substances and Disease Registry (ATSDR). Toxicological Profile for Lead. 2007.

Agency for Toxic Substances and Disease Registry (ATSDR). Toxicological profile for heptachlor and heptachlor epoxide [online]. August 2007. Available at URL:

http://www.atsdr.cdc. gov/toxprofiles/tp12.html. 4/21/09

Agency for Toxic Substances and Disease Registry (ATSDR). Toxicological profile for polycyclic aromatic hydrocarbons 1995 [online]. Available at URL:

http://www.atsdr.cdc.gov/toxprofiles/ tp69.html. 5/26/09

Agency for Toxic Substances and Disease Registry (ATSDR). Toxicological profile for polychlorinated biphenyls. 2000 [online]. Available from URL:

http://www.atsdr.cdc.gov/toxprofiles/tp17. html. 03/17/05.

Agency for Toxic Substances and Disease Registry (ATSDR). Toxicological profile for polycyclic aromatic hydrocarbons 1995 [online]. Available at URL:

http://www.atsdr.cdc.gov/toxprofiles/ tp69.html. 5/26/09

Agency for Toxic Substances and Disease Registry (ATSDR). Toxicological Profile for Mercury. 1999.

Agency for Toxic Substances and Disease Registry (ATSDR). Toxicological Profile for Cadmium. 2008.

Alcock et. Al. Health risks of persistent organic pollutants from long-range transboundary air pollution, World Health Organization 2003.

Alcock R. et. al. (2003). Health risk of persistent organic pollutants from long range transboundary air pollution. World Health Organization

Alivernini S, Battistelli CL, Turrio-Baldassarri L. Human milk as a vector and an indicator of exposure to PCBs and PBDEs: temporal trend of samples collected in Rome. Bull Environ Contam Toxicol. 2011; 87(1):21-5.

Altomare M, Vicari LO, Oliveri Conti G, Condorelli RA, La Vignera S, Asero P, Giuffrida MC, Manag A, Arena G, Fallico R, Calogero C, D'Agata R, Calogero AE, Vicari E. $\mathrm{PCB}$ contamination in an industrial area with high environmental risk of the southeastern Sicily, Riproduzione e Sessualità dalla sperimentazione alla clinica, cleup 2012.

Arisawa K, Takeda H, Mikasa H. Background exposure to PCDDs/PCDFs/PCBs and its potential health effects: a review of epidemiologic studies. J Med Invest. 2005;52(1-2):1021.

ASTDR- U.S. Environmental Protection Agency Research, Locating and Estimating Air Emissions from Sources of Dioxins and Furans, May 1997

ASTDR Public Health Service Agency for Toxic Substances and Disease Registry U.S. Department of Health and Human Services Toxicological Profile for Polychlorinated Biphenyls (PCBs) November 2000).

ASTDR- U.S. Department of Health and Human Services Public Health Service Agency for Toxic Substances and Disease Registry, Addendum to the Toxicological Profile for Chlorinated Dibenzo-p-Dioxins (CDDs), April 2011 
ASTDR- U.S. Department of Health and Human Services Public Health Service Agency for Toxic Substances and Disease Registry, Toxicological Profile for Chlorinated Dibenzo-pDioxins, December 1998

ASTDR-U.S. Department of Health and Human Services Public Health Service Agency for Toxic Substances and Disease Registry, Toxicological Profile for Sulfur Dioxide, 1998

ASTDR-U.S. Environmental Protection Agency Research. (1997). Locating and Estimating air Emissions from Sources of Dioxins and Furans, May.

Bell M, PhD; Roger D. Peng, PhD; Francesca Dominici, PhD; Jonathan M. Samet, MD Emergency Hospital Admissions for Cardiovascular Diseases and Ambient Levels of Carbon Monoxide Results for 126 United States Urban Counties, 1999-2005 Circulation 2009, 120:949-955.

Bocca B, Petrucci F, Alimonti A, Caroli S. Traffic-related platinum and rhodium concentrations in the atmosphere of Rome. J Environ Monit. 2003 Aug;5(4):563-8

Breivik K, Alcock R, Li YF, Bailey RE, Fiedler H, Pacyna JM. Primary sources of selected POPs: regional and global scale emission inventories. Environ Pollut. 2004;128(1-2):316.

Breivik K, Sweetman A, Pacyna JM, Jones KC. Towards a global historical emission inventory for selected PCB congeners--a mass balance approach. 2. Emissions. Sci Total Environ. 2002a May 6;290(1-3):199-224.

Carpenter DO. Polychlorinated biphenyls (PCBs): routes of exposure and effects on human health. Rev Environ Health 2006;21(1):1-23

Consonni D, Sindaco R, Bertazzi PA. Blood levels of dioxins, furans, dioxin-like PCBs, and TEQs in general populations: A review, 1989-2010. Environ Int. 2012 Feb 23.

Corsmeier, U., Kalthoff, N., Kottmeier, Ch., Vogel, B.,Hammer, M., Volz-Thomas, A., Konrad, S., Glaser, K.,Neininger, B., Lehning, M., Jaeschke, W., Memmesheimer, M., Rappenglu“ ck, B., Jakobi, G. Ozone budget and PAN formation inside and outside of the Berlin plume process analysis and numerical process simulation. Journal of Atmospheric Chemistry 2002; 42: 289-321.

Crinnion WJ. Polychlorinated biphenyls: persistent pollutants with immunological, neurological, and endocrinological consequences. Altern Med Rev. 2011 Mar;16(1):513

Department of Health and Human Services Centers for Disease Control and Prevention. (2009), Fourth National Report on Human Exposure to Environmental Chemicals.

EEA, The European environment state and outlook 2010.

EMEP/CORINAIR. (2007). Atmospheric Emissions Inventory Guidebook Group 10: Agriculture (3rd ed.). Copenhagen: European Environment Agency.

Environmental Protection Agency 40 CFR Part 50 [EPA-HQ-OAR-2007-1145] RIN: 2060AO72 “Secondary National Ambient Air Quality Standards for Oxides of Nitrogen and 
Sulfur Final Revisions to Nitrogen and Sulfur Oxides Secondary National Air Quality Standards" 3/20/2012

Environmental Protection Agency . Sources of indoor air pollution - organic gases (Volatile Organic Compounds-VOCs). Available at http://www.epa.gov/iaq/voc.html. Site last updated

Environmental Protection Agency. Sources of indoor air pollution-respirable particles, 2005 a Available at http://www.epa.gov/iaq/rpart.html.

EPA, http://www.epa.gov/pbt/pubs/dioxins.htm

European Environmental Agency (EEA). The European Environment state and outlook, 2010.

Faroon O.M.et. al. (2003), Polychlorinated Biphenyls: Human Health Aspects. WHO.

Ferrante M, Fallico R, Fiore M, Barbagallo M, Castagno R, Salemi M, Caltavituro G, Lombardo C, Manciagli E, Sciacca S. Evaluation of xenobiotics presence in maternal milk. Epidemiology 2006;17:298.

Ferrante M, Fallico R, Fiore M, Brundo MV, Sciacca S. Sustainable development and air quality in the Catania city within. Atti 13th World Clean Air and Environmental Protection. IUAPPA, NSCAEP and ISEEQS. London, 22-27 Agosto 2004.

Ferrante M., Fallico R., Smecca G., Fiore M., Sciacca S. First information about Pt, Pd and Rh in air, foods and biological samples in the district of Catania. 11 th World Clean Air e Environment Congress "The interface between developing and developed countries" IUAPPA Durban, South Africa 14 - 18 September 1998.

Ferrante Margherita, Aldo Calogero, Gea Oliveri Conti, Enzo Vicari, Caterina Ledda Paola Asero, Salvatore Sciacca, Rosario D'Agata. Cadmium toxicity: a possible cause of male infertility., ISEE Barcellona 2011?)

Ferrante Margherita, Aldo Calogero, Gea Oliveri Conti, Vincenzo Vicari, Maria Fiore, Giovanni Arena, Salvatore Sciacca, Rosario D'Agata. As, $\mathrm{Hg}$, and Ni levels in serum and seminal plasma and male fertility. 2011. Abstracts of the 23rd Annual Conference of the International Society of Environmental Epidemiology (ISEE). September 13 - 16, 2011, Barcelona, Spain. Environ Health Perspect.

Firket, J. Fog along the Meuse Valley, Trans. Faraday Soc. 1936;32:1192-1197.

Gies A, Neumeier G, Rappolder M, Konietzka R. (2007). Risk assessment of dioxins and dioxin-like PCBs in food--comments by the German Federal Environmental Agency. Chemosphere. Apr;67(9):S344-9

Green RJ. Inflammatory airway disease. Current Allergy and Clinical Immunology, 2003; 16:181.

Guo H., S.C. Lee, L.Y. Chan, andW.M. Li. Risk assessment of exposure to volatile organic compounds in different indoor environments. Environmental Research 2004;94: 5766.

Henderson J, Sherriff A, Farrow A, Ayres JG. Household chemicals, persistent wheezing and lung function: effect modification by atopy? Eur Respir J 2008; 31: 547-554. 
Johnson DE, Braeckman RA, Wolfgang GH. Practical aspects of assessing toxicokinetics and toxicodynamics. Curr Opin Drug Discov Devel. 1999 Jan;2(1):49-57.

Jones, K.C. \& De Voogt, P. (1999). Persistent organic pollutants (POPs): state of the science. Environmental Pollution (100): 209 \pm 221 .

Lundqvist C, Zuurbier M, Leijs M, Johansson C, Ceccatelli S, Saunders M, et al. (2006). The effects of PCBs and dioxins on child health. Acta Paediatr Suppl;95(453):55-64.

Mendell MJ. Indoor residential chemical emissions as risk factors for respiratory and allergic effects in children: a review. Indoor Air 2007; 17: 259-277.

Minnesota Department of Health (MDH). Volatile Organic Compounds (VOCs) in Your Home. 2010.

Narváez, Lori Hoepner, Steven N. Chillrud, Beizhan Yan, Robin , Garfinkel, Robin Whyatt, David Camann, Frederica P. Perera, Patrick L.Kinney, And Rachel L. Miller. Spatial and Temporal Trends of Polycyclic Aromatic Hydrocarbons and Other TrafficRelated Airborne Pollutants in New York City, Environ Sci Technol. 2008; 42(19): 7330-7335.

Oliveri Conti G, Ledda C, Bonanno, Romeo, Fiore M, Ferrante M. (2011). Evalutation of PHAs in seminal plasma of volunteers from an Sicilian industrialized area. Proceedings of Environmental health Conference 6-9 February 2011 Salvador, Brazil.

Oliveri Conti G, Ledda C, Fiore M, Mauceri C, Sciacca S, Ferrante M. Rinite allergica e asma in età pediatrica e inquinamento dell'ambiente Indoor. Ig. Sanità Pubbl. 2011; 67: 467480 .

Park JW et al. Interleukin-1 receptor antagonist attenuates airway hyperresponsiveness following exposure to ozone. American Journal of Respiratory Cell and Molecular Biology 2004; 30:830-836.

Porta M, López T, Gasull M, Rodríguez-Sanz M, Garí M, Pumarega J, Borrell C, Grimalt JO. Distribution of blood concentrations of persistent organic pollutants in a representative sample of the population of Barcelona in 2006, and comparison with levels in 2002. Sci Total Environ. 2012 Mar

Primo rapporto sullo stato dell'ambiente della Città di Catania, 2001. http://www.liceogalileict.it/Helianthus/catania.pdf

Purkey HE, Palaninathan SK, Kent KC, Smith C, Safe SH, Sacchettini JC, et al. Hydroxylated polychlorinated biphenyls selectively bind transthyretin in blood and inhibit amyloidogenesis: rationalizing rodent PCB toxicity. Chem Biol 2004;11(12):1719-1728.

Ravindra K, Bencs L, Van Grieken R. (2004). Platinum group elements in the environment and their health risk. Science of The Total Environment. 318(1-3):1-43.

Ritter et al, 1995. A review of selected persistent organic pollutants, WHO.

Rumchev K, Spickett J, Bulsara M, Phillips M, Stick S. Association of domestic exposure to volatile organic compounds with asthma in young children. Thorax 2004; 59:746751. 
Safe SH. (1998). Development Validation and Problems with theToxic Equivalency Factor Approach for Risk Assessment of Dioxins and Related Compounds. J ANIM SCI, 76:134-141.

Sciacca Salvatore and Gea Oliveri Conti. Mutagens and carcinogens in drinking water. Mediterranean Journal Of Nutrition And Metabolism. 2009; 2(3):157-162.

Sciacca S, Fallico R, Brundo V.M, Fiore M, Oliveri Conti G, Sinatra M. L, Bella F, Galata' R, Castagno R, Caltavituro P, Cirrone Cipolla A, Ferrante M. Characterization of inhalable particulate matter in Siracusa city. 14th International Union of Air Polllution Prevention and Environmental. Protection Associations (IUAPPA) World Congress 2007 incorporating $18^{\text {th }}$ Clean Air Society of Australia and New Zealand (CASANZ) Conference. Brisbane 9-13 Settembre 2007.

Sexton K, Adgate JL, Ramachandran G, Pratt GC, Mongin SJ, Stock TH, Morandi MT. Comparison of personal, indoor, and outdoor exposures to hazardous air pollutants in three urban communities. Environ Sci Technol 2004; 38:423-430.

Sidiropoulos C. \& Tsilingiridis G.(2009). Trends of Livestock-related $\mathrm{NH}_{3}, \mathrm{CH}_{4}, \mathrm{~N}_{2} \mathrm{O}$ and PM Emissions in Greece. Water Air Soil Pollut , 199:277-289.

SOER 2010. The European Environment. State and outlook 2010. Air pollution. European Environment Agency (EEA). EEA, Copenhagen, 2010. Luxembourg: Publications Office of the European Union, 2010. ISBN 978-92-9213-152-4.

Spaziani F, Angelone M, Coletta A, Salluzzo A, Cremisini C. (2008). Determination of Platinum Group Elements and Evaluation of Their Traffic-Related Distribution in Italian Urban Environments. Analytical Letters; 41(14):2658-2683. DOI:10.1080/00032710802363503.

Vallaci H W, D J Bakker, I Brandt, E Broström-Lundén, A Brouwer, K R Bull, C Gough, R Guardans, I Holoubek, B Jansson,R Koch, J Kuylenstierna, A Lecloux, D Mackay, P McCutcheon, P Mocarelli, R D Taalman. Controlling persistent organic pollutants-what next? Environmental Toxicology and Pharmacology (1998) Volume: 6, Issue: 3, Pages: 143-175

Viegi G, M. Simoni, A. Scognamiglio, S. Baldacci, F. Pistelli, L. Carrozzi, I. Annesi-Maesano "Indoor air pollution and airway disease" INT J TUBERC LUNG DIS 8(12):1401-1415 2004 IUATLD

Vivoli G, Fallico R, Gilli G, Bergomo M, Rovesti S, Vivoli R, Ferrante M, Fiore M, Bono R, Amodio Cocchieri R, Cirillo T. Il monitoraggio biologico nella valutazione dell'esposizione ambientale al benzene. Atti $40^{\circ}$ Congresso Nazionale S.It.I., Como 8-11 Settembre 2002, Relazioni: 126-130.

Weschler CJ. Changes in indoor pollutants since the 1950s. Atmospheric Environment 2009; 43: 153-169.

$\mathrm{WHO}, 2007$. Health relevance of particulate matter from various sources. Report on a WHO Workshop Bonn, Germany, 26-27 March 2007. World Health Organization Regional Office for Europe 
WHO, Air quality guidelines for particulate matter, ozone, nitrogen dioxide and sulfur dioxide, Global Update 2005 , 2006

WHO, Polynuclear aromatic hydrocarbons in Drinking-water, 2003

WHO, Sulfur dioxide Air Quality Guidelines - Second Edition, 2000

WHO, WHO guidelines for indoor air quality: selected pollutants, 2010 